Reprinted from the Journal of Counseling \& Development, Vol. 85, p. 47-52. (C) 2007 The American Counseling Association. Reprinted with permission. No further reproduction authorized with out written permission from the American Counseling Association

\title{
Spirituality and Counselor Competence: A National Survey of American Counseling Association Members
}

\author{
J. Scott Young, Marsha Wiggins-Frame, and Craig S. Cashwell
}

A random sample of 505 American Counseling Association (ACA) members completed a questionnaire that evaluated respondents' ratings of the importance of 9 competencies developed at the Summit on Spirituality (G. Miller, 1999; "Summit Results," 1995) meetings to effectively address spiritual and religious issues in counseling practice. Results suggest that, in general, ACA members strongly support the importance of the competencies for effective counseling practice.

Until recently, many mental health professionals neglected issues related to religion and spirituality in their work with clients (Bergin, 1980, 1983; Frame, 2003; Henning \& Tirrell, 1982; Hodge, 2001; Richards \& Bergin, 1997; Schulte, Skinner, \& Claiborn, 2002; Slife, Hope, \& Nebeker, 1999; Zinnbauer \& Pargament, 2000). Part of the explanation for excluding religion and spirituality from clinical work came from the conflict between the scientific, objective perspective of psychology and the transcendent, subjective aspects of religion (Burke et al., 1999; Lovinger, 1984; Pattison, 1978; Prest \& Keller, 1993; Rayburn, 1985; Reisner \& Lawson, 1992; Wallwork \& Wallwork, 1990). The influence of Freud and, more recently, theorists such as Ellis and Skinner on psychology and the issues of separation of church and state in American politics and culture (Frame, 2003; Kelly, 1995; Myers \& Williard, 2003) also contributed to the chasm between counseling on the one hand and religion and spirituality on the other.

In addition, with the exception of pastoral counselors, few mental health practitioners have received formal training in working with spiritual and religious issues in counseling (Burke et al., 1999; Collins, Hurst, \& Jacobson, 1987; Frame, 2003; Genia, 1994; Jensen \& Bergin, 1988; Schulte et al., 2002; Shafranske \& Malony, 1990). In fact, Kelly (1994) found that only $25 \%$ of 341 accredited and nonaccredited counselor education programs reported that spirituality and religious issues were included as a course component. Further research by Pate and High (1995) and Kelly (1997) revealed higher percentages of programs $(60 \%$ in the Pate \& High, 1995 , study; slightly more than $50 \%$ in the Kelly, 1997, study) accredited by the Council for Accreditation of Counseling and Related Educational Programs (CACREP; 2001) that provided some attention to religious and spiritual issues in their curriculum.

Despite the fact that many counselors do not receive formal training in working with clients' religious and spiritual issues, surveys reveal that approximately $75 \%$ of Americans report that religion and spirituality are important to them (University of Pennsylvania, 2003). Indeed, a majority of families adhere to some religious system for the expression of their spirituality (Campbell \& Moyers, 1988). Because there is such widespread commitment of the general population to some form of spirituality, it is not surprising that when faced with a major difficulty, two thirds of Gallup respondents indicated that they would prefer to see a counselor who held similar spiritual values and beliefs (Lehman, 1993). Furthermore, counselors themselves report spiritual and religious beliefs and practices at rates comparable with those of the general population (Kelly, 1995). Not to address issues of spirituality and religion in counseling is to ignore a vital aspect of clients' lives (Burke et al., 1999; Ellison, 1991; Frame, 2003; Hadaway, Marler, \& Chaves, 1993; Miller, 1999; Wuthnow, 1994).

\section{Rationale for the Study}

Beginning in 1995, a group of American Counseling Association (ACA) members, under the endorsement of the Association of Spiritual, Ethical, and Religious Values in Counseling (ASERVIC) met together in Belmont, North Carolina, at a gathering called the "Summit on Spirituality." The Summit was the result of conversations held by ASERVIC leaders who were interested in infusing spirituality into counseling (Miller, 1999). Mary Thomas Burke and Judy Miranti hosted the first meeting. Fifteen individuals from a cross-section of ACA divisions and representative of various regions of the United States were invited to participate. These persons were selected because they had published articles on spirituality in ACA journals or had written books on the topic (Miller, 1999). By the end of the $2 \frac{1}{2}$-day meeting (which they attended at their own expense), they developed a description of spirituality rather than a definition and generated 10 competencies, which went through several drafts (J. Miranti,

\footnotetext{
J. Scott Young, Department of Counseling, Educational Psychology and Special Education, Mississippi State University; Marsha Wiggins-Frame, Department of Counseling Psychology and Counselor Education, University of Colorado at Denver; Craig S. Cashwell, Department of Counseling and Educational Development, The University of North Carolina at Greensboro. Correspondence concerning this article should be addressed to J. Scott Young, PO Box 9727, Mississippi State, MS 39762 (e-mail: jsyoung @ colled.msstate.edu).
} 
personal communication, May 18,2004$)$. According to this view, spirituality is a

capacity and tendency that is innate and unique to all persons. The spiritual tendency moves the individual toward knowledge, love, meaning, peace, hope, transcendence, connectedness, compassion, wellness, and wholeness. Spirituality includes one's capacity for creativity, growth, and the development of a value system. ("Summit Results," 1995, p. 30)

Religion, by contrast, is the specific organized and codified form through which individuals may express their spirituality. The competencies (see Appendix) developed by participants were considered essential in training counselors to work effectively with clients' religious and spiritual concerns. After the initial Summit on Spirituality, four other sessions were held at ACA and the Association for Counselor Education and Supervision conferences to address infusion of spirituality into counseling (Miller, 1999). These sessions were attended by 35 to 40 counselors and counselor educators (Miller, 1999). Ultimately, nine competencies emerged, and participants proposed that these competencies should be included in the CACREP accreditation standards and infused within the eight core areas of the CACREP curriculum (Burke et al., 1999). Empirical evidence supporting the fact that practicing counselors think the competencies are important and necessary to effective clinical practice is lacking, however.

To date, the closest related research is a study of 94 CACREP-accredited programs, which found that counselor educators generally supported these same competencies ( $M=3.83$ on 5-point scale; Young, Cashwell, Frame, \& Belaire, 2002). Only $46 \%$ of respondents believed, however, that they were prepared or very prepared to integrate material related to spiritual issues in counseling into their teaching and supervision. These findings call into question the consistency of preparation that counselors have received to address such issues when they arise in counseling. Thus, the purposes of this study were to investigate the level of support among ACA members for the spirituality competencies and to provide baseline information on ACA members' current perceptions of their competence in addressing spiritual issues in counseling. Specifically, the following research questions were investigated:

1. How important do respondents believe the proposed competencies are to effectively address spiritual and religious issues in counseling?

2. How well prepared are respondents to address spiritual and religious issues in counseling by practicing in accord with the proposed competencies?

3. Do respondents believe they need additional training to address spiritual and religious issues in counseling?

\section{Method}

\section{Participants}

A random sample of 1,000 members was selected using a computer program designed for this purpose by an ACA staff member in the Management Information Systems department. The sample information was drawn from the ACA membership roll in August 2002 and was forwarded to the researchers (the authors of this article). The final sample consisted of 505 ACA members. Demographic details for the sample are provided in Table 1. Like ACA's overall membership, individuals in the sample tended to be female Caucasians, hold a master's degree, and work in a school setting.

The respondents considered themselves more spiritual $(82 \%$ agreed or strongly agreed) than religious ( $48 \%$ agreed or strongly agreed) when responding to the items "I consider myself to be a spiritual person" and "I consider myself to be a religious person." Sixty-eight percent considered themselves prepared or very prepared to counsel clients with spiritual and/or religious issues. When asked how important it is for counselors to receive formal training in addressing spiritual and religious issues, $68 \%$ $(n=339)$ thought it was either important or very important. Regarding the training participants had received pertaining to spirituality and religion in counseling, $47 \%$ had received course work, $40 \%$ had attended workshops, $50 \%$ had read books and journal articles, $15 \%$ had received pastoral counselor training,

\section{TABLE 1}

\section{Comparative Demographics for Sample and Population of American Counseling Association Members}

\begin{tabular}{|c|c|c|}
\hline Demographic & $\begin{array}{c}\% \text { Sample } \\
(N=505)\end{array}$ & $\begin{array}{c}\% \text { Population } \\
(N=55,437)\end{array}$ \\
\hline \multicolumn{3}{|l|}{ Sex } \\
\hline Female & 74.0 & 72.0 \\
\hline Male & 26.0 & 28.0 \\
\hline \multicolumn{3}{|l|}{ Race } \\
\hline Caucasian & 84.0 & 87.0 \\
\hline African American & 6.4 & 6.0 \\
\hline Hispanic & 2.8 & 2.7 \\
\hline Asian American & 2.4 & 1.5 \\
\hline Native American & 1.4 & 0.9 \\
\hline Other & 1.4 & 1.5 \\
\hline \multicolumn{3}{|l|}{ Educational level } \\
\hline Master's & 72.0 & 86.0 \\
\hline $\mathrm{PhD} / \mathrm{EdD}$ & 14.0 & 17.0 \\
\hline Educational specialist & 5.0 & 0.2 \\
\hline Bachelor's & 8.0 & 11.0 \\
\hline \multicolumn{3}{|l|}{ Work settings } \\
\hline Schools & 24.0 & 19.0 \\
\hline Community agencies & 20.0 & 14.0 \\
\hline Hospital & 13.0 & \\
\hline Private practice & 13.0 & 30.0 \\
\hline Career development & 12.0 & 0.08 \\
\hline Military & 0.4 & 0.06 \\
\hline University/college & 7.0 & 18.0 \\
\hline Church pastoral & 3.0 & 2.0 \\
\hline Government & 1.4 & 0.03 \\
\hline
\end{tabular}

Note. $\mathrm{PhD}=$ doctor of philosophy; $\mathrm{EdD}=$ doctor of education. 
and $18 \%$ had received no training related to this area. (The percentage total is greater than 100 because some respondents had done more than one form of training.)

\section{Survey Instrument}

A two-part questionnaire was constructed using the Summit on Spirituality's list of nine competencies for spiritual issues in counseling (Miller, 1999; see Appendix). In the first portion of the questionnaire, respondents provided demographic information (gender, age, ethnicity, educational background, work setting, years in the profession, their perceptions of their own spirituality and religious orientation, perception of preparedness to work with spiritual/religious issues in counseling, and types of training they had received for addressing spiritual/religious issues in counseling). In the second section, respondents were asked to "Respond to each item by marking the category that best describes the importance of each competency for effective counseling practice." A Likert-type scale, ranging from 1 (very unimportant) to 5 (very important), was provided for each item. A final item asked respondents to indicate on a 5-point Likert-type scale ranging from 1 (very unprepared) to 5 (very prepared), "How well prepared are you to infuse the competencies into your counseling work?" Those individuals who felt unprepared to infuse the competencies in their work were asked to provide specific needs for additional training.

\section{Procedure}

The guidelines for conducting survey research suggested by Dillman (2000) were used, and all potential participants received a copy of a cover letter that outlined the purpose of the research and voluntary participation information. In addition, the questionnaire and a return envelope were provided. All surveys were numbered for tracking purposes. From the initial mailing, 354 respondents returned the completed questionnaire. Six weeks later, nonrespondents received an additional copy of the questionnaire and a return envelope. An additional 151 questionnaires were returned following the second round of mailings, yielding a total return of 505 completed surveys ( $50 \%$ response rate).

\section{Results}

To address the first research question, regarding the importance of the competencies for addressing spirituality and religion in counseling, we calculated descriptive statistics (means and standard deviations). Table 2 shows a comparison of the means and standard deviations for the nine competencies as well as the strength of support based on percentage of respondents marking either agree or strongly agree for each competency. Overall, the competencies received strong support from this sample, with an overall mean rating of 4.2 . No competency received a mean rating lower than 3.5 , indicating greater than moderate support for each of the competencies (see Table 2).

An examination of descriptive statistics related to the second research question, regarding the preparedness of
TABLE 2

\section{Mean Importance and Percentage of Agreement Scores for All Competencies}

\begin{tabular}{|c|c|c|c|c|}
\hline Competency $^{a}$ & $M$ & $S D$ & $\%$ Agree & $95 \% \mathrm{Cl}$ \\
\hline $\begin{array}{l}\text { Sensitivity to } \\
\text { communication ....(5) }\end{array}$ & 4.7 & 1.43 & 92 & $4.64-4.76$ \\
\hline $\begin{array}{l}\text { Limits to own under- } \\
\text { standing ... (6) }\end{array}$ & 4.7 & 0.70 & 92 & $4.64-4.76$ \\
\hline $\begin{array}{l}\text { Respectful of spiritua! } \\
\text { themes .... ( } 8) \\
\text { Engage in self- }\end{array}$ & 4.6 & 0.68 & 92 & $4.54-4.66$ \\
\hline $\begin{array}{l}\text { exploration .... (3) } \\
\text { Assess relevance of }\end{array}$ & 4.3 & 1.02 & 80 & $4.21-4.39$ \\
\hline $\begin{array}{l}\text { spinitual domains ... (7) } \\
\text { Use client's beliefs in }\end{array}$ & 4.1 & 0.95 & 77 & $4.02-4.18$ \\
\hline $\begin{array}{l}\text { treatment.... (9) } \\
\text { Describe practices in a }\end{array}$ & 4.0 & 0.95 & 70 & $3.92-4.08$ \\
\hline $\begin{array}{l}\text { cultural context.... (2) } \\
\text { Explain the relationship }\end{array}$ & 3.8 & 1.02 & 66 & $3.71-3.89$ \\
\hline $\begin{array}{l}\ldots \text { (1) } \\
\text { Explain self/models of }\end{array}$ & 3.8 & 1.03 & 65 & $3.71-3.89$ \\
\hline development ... (4) & 3.5 & 1.15 & 51 & $3.40-3.60$ \\
\hline
\end{tabular}

Note. $N=505 . \mathrm{Cl}=$ confidence interval.

${ }^{\mathrm{a}} \mathrm{A}$ complete list of competencies is available in the Appendix.

respondents to practice in accord with the competencies, revealed that $53 \%$ agreed or strongly agreed that they could do so $(M=3.5, S D=1.04)$. Another $27.9 \%$ marked the neutral response related to this item, whereas $15.6 \%$ either disagreed or strongly disagreed. The final research question considered the training needs of those respondents who felt unprepared to practice in accord with the competencies. Twenty-one percent of the unprepared respondents indicated a need for additional training. The requested support included workshops, seminars, education on various religious and spiritual orientations, focused readings, greater knowledge of referral sources, casebased training, greater self-awareness, and understanding of fundamentalist beliefs.

Additional comparisons were calculated to consider if differences might exist among subsets of the sample group. Analyses of variance were performed using education level, race, and employment setting as the dependent measure; however, no differences were found for any of these comparisons. In addition, correlations were run between survey items pertaining to participants' attitudes and beliefs about their own spiritual and religious perspective and their ratings as to the importance of the competencies. Specifically, there were significant positive correlations between respondents who rated themselves highly on the item "I consider myself to be a spiritual person" and their ratings of most of the competencies (see Table 3 ). There were also significant correlations between individuals who rated themselves highly on the item "I consider myself to be a religious person" and their ratings of some of the competencies (Competencies 1, 2, 3, and 4 were significantly correlated for these participants), although for fewer of the competencies than for the previously mentioned comparison (see Table 3 ). This finding might be explained by the fact that the competencies 
TABLE 3

\section{Correlations of Respondents' Personal Attitudes and Ratings of Competencies}

\begin{tabular}{lcc}
\hline & \multicolumn{2}{c}{$\begin{array}{c}\text { Respondents' Attitudes } \\
\text { Toward Self }\end{array}$} \\
\cline { 2 - 3 } & $\begin{array}{c}\text { Religious } \\
\text { Person }\end{array}$ & $\begin{array}{c}\text { Spiritual } \\
\text { Person }\end{array}$ \\
\hline Competency & $.143^{*}$ & $.347^{*}$ \\
\hline $\begin{array}{l}\text { Engage in self-exploration ...(3) } \\
\text { Explain the relationship ...(1) }\end{array}$ & $.185^{*}$ & $.278^{*}$ \\
$\begin{array}{l}\text { Use client's beliefs in treatment } \\
\ldots(9)\end{array}$ & .036 & $.262^{*}$ \\
$\begin{array}{l}\text { Explain self/models of } \\
\text { development ... (4) }\end{array}$ & $.207^{*}$ & $.245^{*}$ \\
$\begin{array}{l}\text { Assess relevance of spiritual } \\
\text { domains ... (7) }\end{array}$ & .090 & $.208^{*}$ \\
$\begin{array}{l}\text { Respectful of spiritual themes } \\
\ldots(8)\end{array}$ & .030 & $.197^{*}$ \\
$\begin{array}{l}\text { Describe practices in a cultural } \\
\text { context ... (2) }\end{array}$ & $.114^{*}$ & $.184^{*}$ \\
$\begin{array}{l}\text { Sensitivity to communication } \\
\ldots .(5)\end{array}$ & -.084 & .063 \\
$\begin{array}{l}\text { Limits to own understanding } \\
\ldots . .(6)\end{array}$ & .004 & .041 \\
\hline
\end{tabular}

${ }^{a} \mathrm{~A}$ complete list of competencies is available in the Appendix. ${ }^{\circ} p<.05$.

were designed to be inclusive and to facilitate counselors' being open to multiple religious perspectives; consequently, more highly religious counselors might find the all-encompassing language of the competencies less in line with their specific religious perspective. Also of interest is the finding that a significant correlation was found with the item "It is important for counselors to receive formal training in addressing spiritual and/or religious issues in counseling" and respondents' rating of the importance of each of the nine competencies under investigation.

\section{Discussion}

Over the past 20 to 30 years, researchers who looked at the interface of religion and psychology found that the average mental health practitioner was less religious than the average client (Kelly, 1995). Nevertheless, there has been a growing dialogue within the helping professions as to the role of religion and spirituality in clinical work. Since that time, there has been much theoretical discussion but little research regarding how these issues actually play out in the counseling interview. This study represents the first national survey of counselors' opinions as to the importance of competencies related to the interface of spirituality and religion with counseling practice. The competencies were endorsed by the current sample, with an overall mean rating of 4.2 on a 5 -point scale. The finding that the majority of counselors believed that these specific competencies are important is interesting for both practitioners and educators. The current results may represent a documented shift in opinions among a broad spectrum of counseling practitioners regarding the relevance of spiritual and religious issues in clinical work. In a recent study that investigated the perceptions of counselor educators regarding the importance of these same competencies, Young et al. (2002) found that among a sample of 69 counselor educators from different CACREP-accredited programs, there appeared to be greater than moderate support for the competencies. Therefore, the current finding that practicing counselors also regard these competencies as important to counseling practice raises several considerations for the future.

First, the need for developing curricular and training guidelines is evident. Sixty-eight percent of the participants strongly agreed that formal training in addressing spiritual and/or religious issues in counseling was important, yet $43.5 \%$ marked the response indicating strong disagreement, disagreement, or neutrality about their ability to practice in accord with the competencies. To date, there is a dearth of research on what counselors-in-training are actually being taught about these issues. In one of the few available studies, Cashwell and Young (2004) were able to obtain copies of syllabi from 14 counselor education programs that offer a course on spirituality and religion. Among these syllabi, there existed a great deal of variation in terms of what was included in the courses. Only $21.4 \%$ of the syllabi included activities that gave considerable focus to the spirituality competencies, whereas $28.5 \%$ of the syllabi demonstrated little to no consistency with the competencies. Because of the support of the competencies by practitioners, counselor education programs may consider using the competencies to create curricular experiences for students. Either a specific course may be developed (Ingersoll, 1997) or an infusion model (Burke et al., 1999) may be used. For many programs, an infusion model may be preferable. With this approach, knowledge about spirituality and counseling is infused into the eight core CACREP curricular areas (human growth and development, social and cultural foundations, helping relationships, group work, career and lifestyle development, appraisal, research and program evaluation, and professional orientation), as suggested by Burke et al.

Second, there is a need for research that demonstrates how counselors can objectively evaluate the role of spirituality and/or religion in clients' issues as well as determine appropriate means for drawing on the existing spiritual assets of a particular client to facilitate therapeutic change. There are models that describe how spirituality fits with the overall psychological functioning of the individual, including Psychosynthesis (Firman \& Vargiu, 1996), Wellness (Chandler, Holden, \& Kolander, 1992), and Transpersonal (Walsh \& Vaughn, 1996). However, there is a need for empirical research to substantiate these constructs.

Third, there is a need to move spirituality and religion from a trend in the field to a codified area of research on several fronts, including the role it plays in the development of psychological disorders and recovery from and prevention of disorders. On a related topic, there is a need for validated methods of incorporating positive spirituality into counsel- 
ing as a mechanism to enliven existing treatment approaches and to facilitate the development of yet unknown interventions. Such interventions as prayer, incorporating scripture, meditation, bibliotherapy, forgiveness, and surrender have been discussed (Frame, 2003), yet clear evidence of their clinical impact remains scant. As Jung (1964) stated, "it is the role of religious symbols to give a meaning to the life of man" (p. 76). Both practitioners and researchers would be remiss to not make every effort to understand how this natural tendency can be drawn upon in counseling.

Fourth, there is a need to investigate the nine competencies under consideration in this study in a systematic fashion. As indicated earlier, these competencies were developed by a panel of experts and should now be submitted to the rigors of empirical investigation to determine their relevance to treatment. For example, it is not known if therapeutic strategies that incorporate client spiritual beliefs are more effective in remedying psychological distress. In this same vein, empirical investigation of how and when client spiritual beliefs are best brought into the therapeutic discussion is warranted.

Finally, given the infancy of this line of research, there is a need for greater dialogue in the professional literature as to how practitioners are currently working with spiritual and/or religion issues. Case studies, single-subject studies, and qualitative research designs would facilitate the development of clinical practice.

\section{Limitations}

The results of the current study should be examined within the context of the current study's limitations. First, respondents reported fairly high self-perceived levels of spirituality. Eight-two percent marked strongly agree or agree to the item "I consider myself to be a spiritual person." It is unknown how practitioners who consider themselves to be less spiritual might respond differently to the survey and have different training needs. Second, it is unknown how individuals who chose not to reply to the survey may differ from those who participated in the study. It is possible that these two limitations are related. In other words, it is possible that those individuals who received the survey and were less supportive of the inclusion of spirituality in counseling did not return the questionnaire.

\section{Conclusion}

Results of the current study provide empirical support for the relevance to practicing counselors of the competencies developed at the Summit on Spirituality ("Summit Results," 1995). Although caution should be used in generalizing the findings to those practitioners who may be less personally oriented toward spiritual perspectives and the integration of spirituality into the counseling process, the results provide evidence that a sizable portion of counselors do believe that such material is important to counseling practice. Further- more, training opportunities now need to extend beyond self-awareness components to include training that provides opportunities to understand conceptual models and intervention techniques, along with research findings that provide counselors more direction in intervening with spiritual issues within the counseling relationship.

\section{References}

Bergin, A. E. (1980). Psychotherapy and religious values. Journal of Counseling and Clinical Psychology, 48, 75-105.

Bergin, A. E. (1983). Religiosity and mental health: A critical reevaluation and meta-analysis. Professional Psychology: Research and Practice, 14, 170-184.

Burke, M. T., Hackney, H., Hudson, P., Miranti, J., Watts, G. A., \& Epp, L. (1999). Spirituality, religion, and CACREP curriculum standards. Journal of Counseling \& Development, 77. 251-257.

Campbell, J., \& Moyers, B. (1988). The power of myth. New York: Doubleday.

Cashwell, C. S., \& Young, J. S. (2004). Spirituality in counselor training: A content analysis of courses taught in CACREP-accredited programs. Counseling and Values, 48, 96-109.

Chandler, C. K., Holden, J. M., \& Kolander, C. A. (1992). Counseling for spiritual wellness: Theory and practice. Journal of Counseling \& Development, 71, 168-175.

Collins, J. R., Hurst, J. C., \& Jacobson, J. K. (1987). The blind spot extended: Spirituality. Journal of College Student Personnel, 28, 274-276.

Council for Accreditation of Counseling and Related Educational Programs. (2001). 2001 standards. Retrieved August 23, 2006, from http://www.cacrep.org/2001Standards.html

Dillman, D. A. (2000). Mail and Internet surveys: The tailored design method. New York: Wiley.

Ellison, C. G. (1991). Religious involvement and subjective well-being. Journal of Health and Social Behavior; 32, 80-99.

Firman, J., \& Vargiu, J. G. (1996). Personal and transpersonal growth: The perspective of psychosynthesis. In S. Boorstein (Ed.), Transpersonal psychotherapy (pp. 117-142). Albany: State University of New York Press.

Frame, M. W. (2003). Integrating religion and spirituality into counseling. Pacific Grove, CA: Brooks/Cole.

Genia, V. (1994). Secular psychotherapists and religious clients: Professional considerations and recommendations. Journal of Counseling \& Development, 72, 395-398.

Hadaway, C. I., Marler, P. L., \& Chaves, M. (1993). What the polls don't show: A closer look at U.S. church attendance. American Sociological Review, 58, 741-752.

Henning, L. H., \& Tirrell, F. J. (1982). Counselor resistance to spiritual exploration. The Personnel and Guidance Journal, 61, 92-95.

Hodge, D. R. (2001). Spiritual assessments: A review of major qualitative methods and a new framework for assessing spirituality. Social Work, 46, 203-214. 
Ingersoll, R. E. (1997). Teaching a course on counseling and spirituality. Counselor Education and Supervision, 36, 224-232.

Jensen, J. P., \& Bergin, A. E. (1988). Mental health values of professional therapists: A national interdisciplinary survey. Professional Psychology: Research and Practice, 19, 290-297.

Jung, C. G. (1964). Man and his symbols. New York: Dell.

Kelly, E. W., Jr. (1994). Counselor preparation: The role of religion and spirituality in counselor education: A national survey. Counselor Education and Supervision, 33, 227-237.

Kelly, E. W., Jr. (1995). Spirituality and religion in counseling and psychotherapy. Alexandria, VA: American Counseling Association.

Kelly, E. W., Jr. (1997). Religion and spirituality in variously accredited counselor training programs: A comment on Pate and High (1995). Counseling and Values, 42, 7-11.

Lehman, C. (1993, January 30). Faith-based counseling gains favor. The Washington Post, pp. B7-B8.

Lovinger, R. J. (1984). Working with religious issues in therapy. New York: Jason Aronson.

Miller, G. (1999). The development of the spiritual focus in counseling and counselor education. Journal of Counseling \& Development, 77, 498-501.

Myers, J. E., \& Williard, K. (2003). Integrating spirituality into counselor preparation: A developmental wellness approach. Counseling and Values, 47, 142-155.

Pate, R. H., \& High, H. J. (1995). The importance of client religious beliefs and practices in the education of counselors in CACREPaccredited programs. Counseling and Values, 40, 2-5.

Pattison, E. M. (1978). Psychiatry and religion circa 1978: An analysis of a decade (Parts I and II). Pastoral Psychology, 27, 8-12, 199-147.

Prest, L. A., \& Keller, J. F. (1993). Spirituality and family therapy: spiritual beliefs, myths, and metaphors. Journal of Marital and Family Therapy, 19, 137-148.

Rayburn, C. A. (1985). The religious patient's initial encounter with psychotherapy. In E. M. Stern (Ed.), Psychotherapy of the religiously committed patient (pp. 35-46). New York: Hayworth.

Reisner, A. D., \& Lawson, P. (1992). Psychotherapy, sin and mental health. Pastoral Psychology, 40, 303-311.

Richards, P. S., \& Bergin, A. E. (1997). A spiritual strategy for counseling and psychotherapy. Washington, DC: American Psychological Association.

Schulte, D. L., Skinner, T. A., \& Claiborn, C. D. (2002). Religious and spiritual issues in counseling psychology training. The Counseling Psychologist, 30, 118-134.

Shafranske, E. P., \& Malony, H. N. (1990). Clinical psychologists' religious and spiritual orientations and their practice of psychotherapy. Psychotherapy, 27, 72-78.
Slife, B. D., Hope, D., \& Nebeker, R. S. (1999). Examining the relationship between religious spirituality and psychological science. Journal of Humanistic Psychology, 39, 51-85.

Summit results in formation of spirituality competencies. (1995, December). Counseling Today, p. 30.

University of Pennsylvania. (2003). New Penn/Gallup poll measures "Spiritual state of the union." Philadelphia: Author.

Wallwork, E., \& Wallwork, A. S. (1990). Psychoanalysis and religion: A historical antagonism. In J. A. Smith \& S. A. Handelman (Eds.), Psychoanalysis and religion (pp. 160-173). Baltimore: Johns Hopkins University Press.

Walsh, R., \& Vaughn, F. E. (1996). Comparative models of the person and psychotherapy. In S. Boorstein (Ed.), Transpersonal psychotherapy (pp. 15-30). Albany: State University of New York Press.

Wuthnow, R. (1994). Sharing the journey: Support groups and America's new quest for community. New York: Free Press.

Young, J. S., Cashwell, C. S., Frame, M. W., \& Belaire, C. (2002). Spiritual and religious competencies: A national survey of CACREPaccredited programs. Counseling and Values, 47, 22-33.

Zinnbauer, B. J., \& Pargament, K. I. (2000). Working with the sacred: Four approaches to religion and spiritual issues in counseling. Journal of Counseling \& Development, 78, 162-171.

\section{APPENDIX}

\section{Counselor Competencies: Spiritual and Religious Issues in Counseling}

1. A counselor should be able to explain the relationship between religion and spirituality, including similarities and differences.

2. A counselor should be able to describe religious and spiritual beliefs and practices within a cultural context.

3. A counselor should engage in self-exploration of his/her religious and spiritual beliefs in order to increase sensitivity, understanding, and acceptance of his/her belief system.

4. A counselor should be able to describe his/her religious and/or spiritual belief system and explain various models of religious/ spiritual development across the life span.

5. A counselor should demonstrate sensitivity to and acceptance of a variety of religious and/or spiritual expressions in the client's communication.

6. A counselor should identify the limits of his/her understanding of a client's spiritual expression and demonstrate appropriate referral skills and general possible referral sources.

7. A counselor should assess the relevance of the spiritual domains in the client's therapeutic issues.

8. A counselor should be sensitive to and respectful of the spiritual themes in the counseling process as befits each client's expressed preferences.

9. A counselor should use client's spiritual beliefs in the pursuit of the client's therapeutic goals as befits the client's expressed preferences. 